\title{
A STUDY ON FISSION TRACK DATING OF GARNET AND ITS APPLICATION IN TECTONICS
}

\author{
SHICHENG WANG *, CHENG-HONG CHEN ** AND JUNG-LI TEIN ** \\ *Department of Nuclear Analysis, Institute of High Energy Physics, \\ 100080 Beijing, China \\ **Department of Geology, National Taiwan University, 10764 Taipei,Taiwan
}

\begin{abstract}
Fission track study has been conducted on the miarolitic garnet from Zhangzhou Igneous Complex. It is found that the garnet is of $\mathrm{Mn}$ - and Fe-rich type; its uranium concentration ranges from 0.2 to $0.8 \mu \mathrm{g} / \mathrm{g}$, with an average of $0.7 \mu \mathrm{g} / \mathrm{g}$; fission track age of the garnet is $73.4 \pm 2.8 \mathrm{Ma}$; and induced fission track length and spontaneous fission track length are $11.5 \pm 0.7 \mu \mathrm{m}$ and $11.0 \pm 0.8 \mu \mathrm{m}$, respectively. These data were used to constrain evolution of the granite body.
\end{abstract}

\section{KEYWORDS}

Garnet; fission track; evolution of granite body.

\section{INTRODUCTION}

Only a few papers on garnet fission track dating have been reported so far (Lal et al., 1976; Haack and Gramse, 1972). Garnets are typical constituents of metamorphic rocks and occur ubiquitously. The chemical composition of garnets varies with geological environments. The concentration of uranium in andradite and spessartine-rich varieties is much higher than in other varieties. After etching in boiling $\mathrm{NaOH}$ solution, spontaneous fission tracks in garnet are easy to recognize. These varieties of garnets are ideal mineral for fission track dating. Garnet fission tracks are very resistant to thermal effect. Its closure temperature is about $260-280^{\circ} \mathrm{C}$ (Wagner and Van den haute, 1992; Haack and Potts, 1972), close to closure temperature of fission tracks in sphene. Garnet fission track may provide thermal history information in this region of temperature.

The garnet used in present study was from the Xincun Unit of Fujian Zhangzhou Igneous Complex. This complex is poor in both apatite and zircon, but is rich in garnet. In this presentation fission track dating of garnet was studied to obtain information on evolution of the granite body.

\section{GEOLOGICAL BACKGROUND OF SAMPLES}

The Zhangzhou Igneous Complex lies along the east-south coast from Zhangzhou to Changtai in Fujian Province, China. The complex is divided into 8 units. The Xincun Unit is located in eastern part of the granite body and has a form of northeast trending narrow strip. This unit belongs to medium-grained miarolitic granite. It is composed of quartz, plagioclase, K-feldspar and biotite, as well as a small amount of garnet. Miarolites are widely dispersed as veins in the complex. Miarolitic minerals include quartz, garnets, K-feldspar and muscovite. The miarolitic garnet has a dark brown color. Its largest size is about $7 \mathrm{~mm}$. 


\section{EXPERIMENTAL PROCEDURE}

1. Preparation of sample. One garnet grain (size of $2 \mathrm{~mm}$ ) was crushed into pieces, which were cleaned in an ultrasonic bath and mounded in epoxy resin on microscope slides, then ground and polished to reveal internal surfaces.

2. Chemical etching. The mounts were etched in boiling $\left(\sim 150^{\circ} \mathrm{C}\right) 50 \mathrm{~mol} / 1 \mathrm{NaOH}$ solution for 20 30 min to reveal spontaneous fission tracks in the garnet.

3. Neutron irradiation. After etching, garnet mounts were cleaned and warped up in intimate contact with low uranium muscovite external detectors and irradiated in the reactor at Xinghua University. The NBS standard glass SRM 612 was used to monitor thermal neutron dose. The muscovite external detectors were etched in $25{ }^{\circ} \mathrm{C} 40 \% \mathrm{HF}$ for $50 \mathrm{~min}$. Neutron fluence $\phi=B \times \rho_{d}$, where $\rho_{d}$ is the induced fission track density from U-235 on muscovite external detector of standard glass; $B$ is calibration factor. $B=5.6 \times 10^{9}$ neutrons / track. Using this value of $B$ to measure thermal neutron fluence and $\lambda_{f}$ value of $7.03 \times 10^{-17} \mathrm{a}^{-1}$, the fission track age of the apatite from Fish Canyon Tuff was measured to be $29.2 \pm 1.9 \mathrm{Ma}$, which is in agreement with $27.77 \mathrm{Ma}$ within $5 \%$ relative error.

4. Fission track age. Track counting was carried out under a Nikon microscope with a magnification of $2500 \times$. Fission track age and its error are calculated using equation of (1) and (2), respectively.

$$
\begin{aligned}
& T=\frac{1}{\lambda_{d}} \ln \left[1+\frac{\lambda_{d} \phi \sigma \lg \rho_{s}}{\lambda_{f} \rho_{i}}\right] \\
& S=T\left[\left(1 / N_{s}\right)+\left(1 / N_{i}\right)+\left(1 / N_{d}\right)\right]^{1 / 2}
\end{aligned}
$$

Where, $\rho_{s}$ and $N_{s}, \rho_{i}$ and $N_{i}, \rho_{d}$ and $N_{d}$ are spontaneous fission track density and number from ${ }^{238} \mathrm{U}$ on garnet, induced fission track density and number from ${ }^{235} \mathrm{U}$ on muscovite external detector, and induced fission track density and number from ${ }^{235} \mathrm{U}$ on muscovite external detector of standard glass, respectively; $\phi$ is thermal neutron fluence (neutrons $/ \mathrm{cm}^{2}$ ); $\lambda_{d}$ is total decay constant for ${ }^{238} \mathrm{U}$ $\left(1.551 \times 10^{-10} \mathrm{a}^{-1)} ; \lambda_{f}\right.$ is decay constant for spontaneous fission of ${ }^{238} \mathrm{U}\left(7.03 \times 10^{-17} \mathrm{a}^{-1}\right)$; $\sigma$ is cross section for thermal neutron induced fission of ${ }^{235} \mathrm{U}\left(580.2 \times 10^{-24} \mathrm{~cm}^{2}\right) ; I$ is isotope ratio of ${ }^{235} \mathrm{U} /{ }^{238} \mathrm{U}$ $\left(7.26 \times 10^{-3}\right)$.

5. Fission track length. Lengths of tracks, which cut the mineral surface, usually are shorter than their total lengths. The lengths of confined fission tracks (TINT or TINCLE) are close to total lengths of tracks. Confined fission track lengths on garnet were measured at a magnification of $2500 \times$ with a precision of $\pm 0.2 \mu \mathrm{m}$.

6. Uranium concentration in garnet. Garnet mounts with muscovite external detector were irradiated with thermal neutrons. The muscovite was etched to reveal induced fission tracks. The uranium concentration $C_{u}$ in the garnet was calculated from induced fission track density $\rho_{i}$ on muscovite and thermal neutron fluence $\phi$ using equation (3).

$$
C_{u}=7.84 \times 10^{10} \rho_{i} / \phi(\mu \mathrm{g} / \mathrm{g})
$$




\section{EXPERIMENTAL RESULTS AND DISCUSSION}

\section{Composition of garnet and its uranium concentration}

Chemical composition of the garnet was determined by microprobe analysis. The results show that the garnet is composed of $77 \% \mathrm{Mn}$-rich spessartine and $22 \% \mathrm{Fe}$-rich almandine.

Uranium concentration in garnet varies from a few $\mathrm{ppb}$ to $\mathrm{ppm}$, depending on its composition. Only for uranium-rich garnets enough fossil fission tracks can be found for dating. In order to establish the suitability of the garnet for fission track dating, concentration and distribution of uranium in the garnet were measured.

The uranium concentrations of $\mathbf{5 2}$ grains of garnet were measured. It is shown from the results that the uranium concentration ranges from 0.2 to $1.8 \mu \mathrm{g} / \mathrm{g}$, with an average value of $0.7 \mu \mathrm{g} / \mathrm{g}$, which is low but still suitable for fission track dating. However the uniformity of uranium distribution is poor, which makes it necessary to apply the external detector method.

\section{Determination of geometry factor $g$}

The geometry factor $g$ should be 0.5 for the external detector method. It means that the mineral and muscovite external detector register fission tracks with the same efficiency. It is not sure that in garnet this is the case. The experimental measurement of the value of $g$ was carried out. Garnet mounts in intimate contact with muscovite were irradiated in the reactor. After neutron irradiation and etching, the densities of fission tracks both on external surfaces of the garnet and on the muscovite were measured to be $7.8 \times 10^{5}$ and $7.4 \times 10^{5}$ tracks $/ \mathrm{cm}^{2}$, respectively. Subtracting the density of fossil tracks on the garnet $\left(0.2 \times 10^{5}\right.$ tracks $\left./ \mathrm{cm}^{2}\right)$, the density of induced fission tracks on the garnet is $7.6 \times 10^{5}$ tracks $/ \mathrm{cm}^{2}$. The background of induced fission tracks on the muscovite irradiated with a neutron fluence of $3 \times 10^{16} \mathrm{n} / \mathrm{cm}^{2}$ was measured to be $1 \times 10^{3}$ tracks $/ \mathrm{cm}^{2}$. It is shown from the results that garnet and muscovite register fission tracks with nearly the same efficiency. The geometry factor was calculated to be 0.49 .

\section{Fission track age determination}

Table 1. Fission track age of the miarolitic gamet.

\begin{tabular}{cccccccc}
\hline $\begin{array}{c}\text { Number of } \\
\text { Grains(n) }\end{array}$ & $\begin{array}{c}\rho_{\mathrm{s}}\left(\mathrm{N}_{\mathrm{s}}\right) \\
\left(10^{4} \mathrm{~cm}^{-2}\right)\end{array}$ & $\begin{array}{c}\rho_{\mathrm{i}}\left(\mathrm{N}_{\mathrm{L}}\right) \\
\left(10^{4} \mathrm{~cm}^{-2}\right)\end{array}$ & $\begin{array}{c}\rho_{\mathrm{d}}\left(\mathrm{N}_{\mathrm{d}}\right) \\
\left(10^{4} \mathrm{~cm}^{-2}\right)\end{array}$ & $\begin{array}{c}\phi \\
\left(10^{16} \mathrm{n} \mathrm{cm}^{-2}\right)\end{array}$ & $\begin{array}{c}\mathrm{P}\left(\chi^{2}\right) \\
(\%)\end{array}$ & $\begin{array}{c}\mathrm{T} \pm \mathrm{S} \\
(\mathrm{Ma})\end{array}$ \\
\hline \multirow{2}{*}{36} & 2.034 & 26.34 & 570.4 & 3.19 & 0.997 & $>99$ & $73.4 \pm 2.8$ \\
& $(929)$ & $(12026)$ & $(3776)$ & & & & \\
\hline
\end{tabular}

The external detector method was used in this work. After etching in $\mathrm{NaOH}$ solution garnet has very clear surface with few defeats and inclusions. Fission tracks on garnet have cone shape (Fig. 1). Track counting is therefore easy. The result of the fission track age determination is shown in Table 1.

In Table $1, \gamma$ is relative coefficient between $N_{s}$ and $N_{i}, P\left(\chi^{2}\right)$ is the probability of observed $\chi^{2}$ value for $(\mathrm{n}-1)$ degrees of freedom. $P\left(\chi^{2}\right)>5 \%$ shows that all single grain ages for 36 garnet grains are compatible with a single group with pooled age of $73.4 \mathrm{Ma}$. The single grain ages of 36 grains show a narrow Gaussion distribution (Fig. 2). 


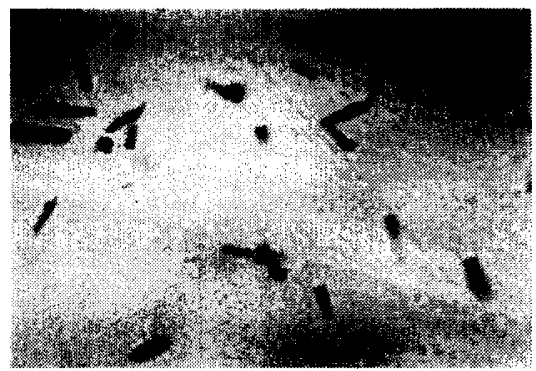

Fig. 1. Induced fission tracks in the miarolitic garnet.

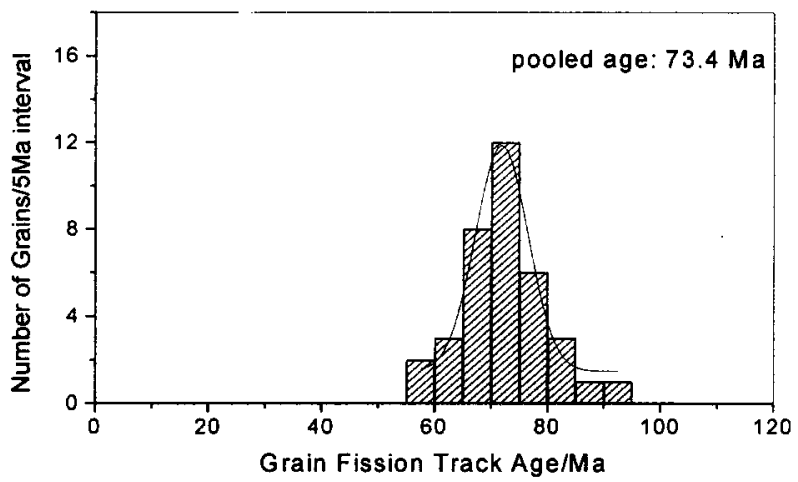

Fig. 2. Distribution of single grain ages for the miarolitic garnet.

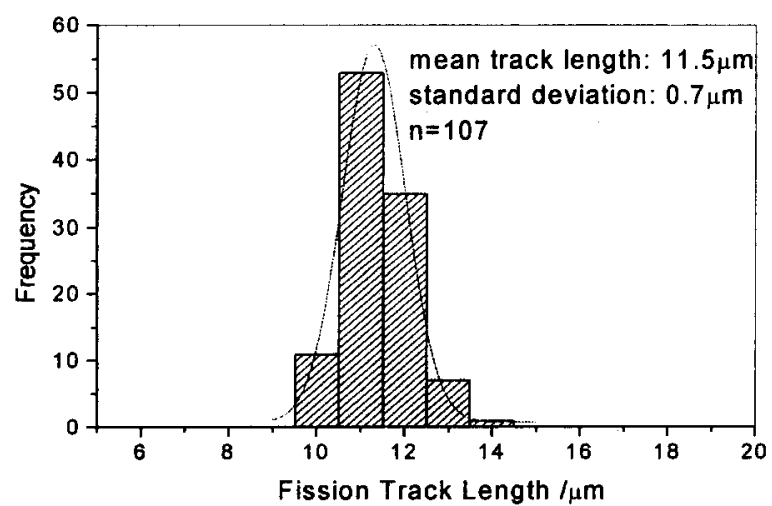

Fig. 3. Distribution of induced fission track lengths for the miarolitic garnet. 


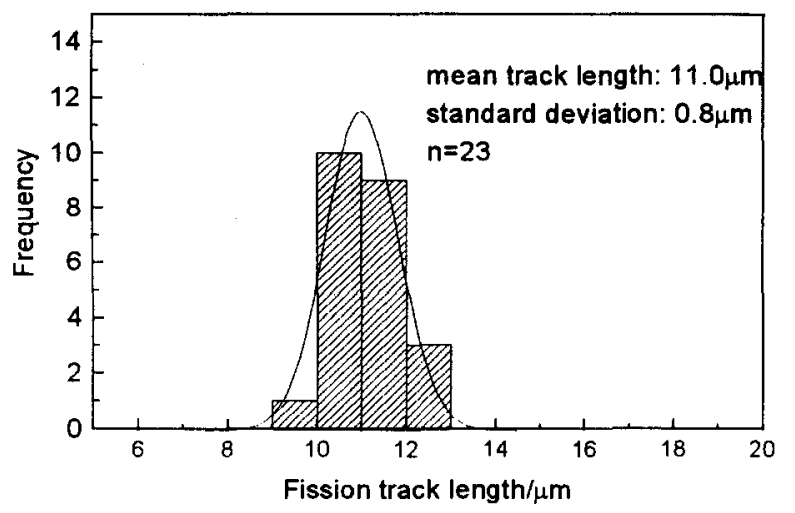

Fig. 4. Distribution of spontaneous fission track lengths for the miarolitic gamet.

\section{The measurement of fission track length}

When the garnet was irradiated with a neutron fluence of $(3-6) \times 10^{16} \mathrm{n} / \mathrm{cm}^{2}$, the induced fission track density from U-235 was in the range of $2 \times 10^{5}-2 \times 10^{6}$ tracks $/ \mathrm{cm}^{2}$. A lot of confined fission tracks formed in such a high track density. The distribution of induced fission track lengths on garnet is a narrow, symmetric Gaussion distribution (Fig. 3), which is characteristic of a track length distribution without any track fading. The mean induced fission track length in garnet is $11.5 \pm 0.1 \mu \mathrm{m}$ with a standard deviation of $0.7 \mu \mathrm{m}$.

The spontaneous fission track density on the surface of the garnet is in the range from $6 \times 10^{3}$ to $6 \times 10^{4}$ tracks $/ \mathrm{cm}^{2}$. In this case the probability having TINT and TINCLE's is very low. Only 23 confined fission tracks were found. The distribution of spontaneous fission track lengths also is a narrow and symmetric Gaussion distribution (Fig. 4). The mean length of spontaneous fission tracks is $11.0 \pm 0.2 \mu \mathrm{m}$ with a standard deviation of $0.8 \mu \mathrm{m}$.

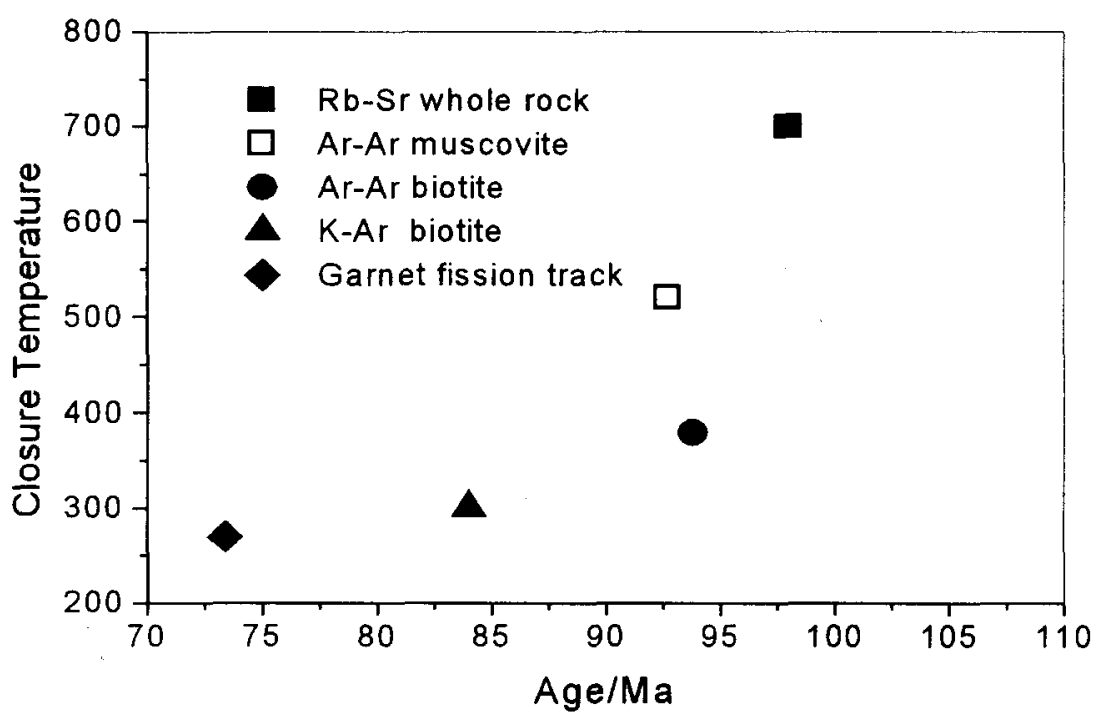

Fig. 5. Cooling history of selected samples from the Xincun Unit, based on data of Rb-Sr, K-Ar, Ar-Ar and garnet fission tracks. 
The length distribution of spontaneous fission tracks is similar to the one of induced fission tracks. It means that miarolitic garnet experienced a rapid cooling process after formation. The garnet has never been subjected to high temperature sufficient to anneal fission tracks obviously since its formation. Thus the garnet fission track age of 73.4 Ma gives the time of cooling and passing through the closure temperature of garnet fission tracks $\left(260-280^{\circ} \mathrm{C}\right.$ ) (Wagner and Van den haute, 1992) and approaches the garnet formation age.

Isotope geological data show that the formation of the Zhangzhou Igneous Complex experienced seven epochs of intrusion in a period of $26 \mathrm{Ma}$. The Xincun Unit is the product of the sixth epoch of intrusion. The garnet fission track age, $\mathrm{Rb}-\mathrm{Sr}$ age, $\mathrm{K}-\mathrm{Ar}$ age and $\mathrm{Ar}-\mathrm{Ar}$ age of the Xincun Unit (Tien, 1996; Zhou et al., 1994) and their closure temperatures are plotted in Fig. 5. It is shown from Fig. 5 that the Xincun Unit formed before $97 \mathrm{Ma}$. It cooled rapidly at a cooling rate of about $100^{\circ} \mathrm{C} / \mathrm{Ma}$ during the first $10 \mathrm{Ma}$. After then, cooling was getting slow and the cooling rate decreased to $10^{\circ} \mathrm{C} / \mathrm{Ma}$. From the position of fission track age of miarolitic garnet in the cooling curve, it seems that the miarolitic garnet formed after emplacement of the granite body, while it was already cooled down to a temperature lower than $300^{\circ} \mathrm{C}$.

Acknowledgments--We would like thank Prof. Tsung-kwei Liu, Dr. Chi-yu Li and Ms.Tsui-chiung Li for their experimental assistance.

\section{REFERENCES}

Haack U.K. and Gramse M. (1972) Survey of garnet for fossil fission tracks. Contr. Mineral. Petrol. 34, 258-260.

Haack U.K. and Potts M.J. (1972) Fission track annealing in garnet. Contr. Mineral. Petrol. 34, 343-345.

Tein Jung-Li (1996) Comparative Study of Fission Track Dating and Ar/Ar Dating of Fujian Late Yanshanian Granitic Complexes, Se China. Ph.D. Thesis, Department of Geology, National Taivan University, Taipei, pp. 216-225.

Lal N., Nagpaul K.K. and Sharma K. K. (1976) Fission track ages and uranium concentration in garnets from Rajasthan, India. Geological Society of American Bulletin, 87, 687-690.

Wagner G. and Van den haute P. (1992) Fission Track Dating. Kluwer Academic Publisher, 169170.

Zhou Xunruo and Wu Kelong (1994) Zhangzhou l-A type Granite, Science Press, Beijing, pp. 6-8. 